\title{
Association of CATSPER1, SPATA16 and TEX11 genes polymorphism with idiopathic azoospermia and oligospermia risk in Iranian population
}

\author{
Mohammadreza Behvarz ${ }^{1}$, Seyyed Ali Rahmani ${ }^{2 *}$, Elham Siasi Torbati ${ }^{1}$, Shahla Danaei Mehrabad ${ }^{3}$ and
} Maryam Bikhof Torbati ${ }^{4}$

\begin{abstract}
Background: Male infertility is a heterogeneous disease which can occur due to spermatogenesis defects. The idiopathic azoospermia and oligospermia are the common cause of male infertility with unknown underlying molecular mechanisms. The aim of this study was to investigate association of idiopathic azoospermia and oligospermia with single-nucleotide polymorphisms of CATSPER1, SPATA16 and TEX11 genes in Iranian-Azeri men.

Methods: In this case-control study, we recruited 100 infertile men (case group) and 100 fertile men (control group) from Azeri population in north western provinces, Iran, population. The genomic DNA was extracted using a proteinase K method from peripheral blood leukocytes. The genotypes analysis was conducted using tetra-primer amplification refractory mutation system-polymerase chain reaction method. The obtained data were analyzed by statistical software.

Results: We found a significant difference in the frequencies of heterozygote $A B$ and mutant homozygote BB genotypes in the CATSPER1 (rs2845570) gene polymorphism between patients and healthy controls $(p<0.05)$. Moreover, we observed a significant difference in the frequencies of heterozygote BA genotype in the SPATA16 (rs1515442) gene polymorphism between patients and healthy controls $(p<0.05)$. However, no significant difference was found in genotypes distribution of case and control groups in the TEX11 (rs143246552) gene polymorphism.

Conclusion: Our finding showed that the CATSPER1 (rs2845570) and SPATA16 (rs1515442) genes polymorphism may play an important role in idiopathic azoospermia and oligospermia in Iranian Azeri population. However, more extensive studies with larger sample sizes from different ethnic origins are essential for access more accurate results.
\end{abstract}

Keywords: Male infertility, CATSPER1, SPATA16, TEX11, Polymorphism

*Correspondence: rahmaniseyedali@yahoo.com

${ }^{2}$ Department of Medical Genetics, School of Medicine, Tabriz University

of Medical Sciences, Tabriz, Iran

Full list of author information is available at the end of the article

\section{Background}

Infertility is defined by the world health organization as a disorder of reproductive system that is one of the important problems in $10-15 \%$ of couple worldwide, which male infertility factors are responsible for $20-30 \%$ of all human infertility cases $[1,2]$. One of the common cause of the male infertility is defects in quality and quantity of sperm, which can occur by effects of genetic variants and 
environmental factors $[3,4]$. The idiopathic azoospermia and oligospermia are common spermatogenesis disorders in men, and is observed in a high proportion of infertile men [5]. However, the underlying molecular mechanisms of the spermatogenesis defects remain unknown $[6,7]$.

Evidences suggested that male infertility can occur due to mutations or single-nucleotide polymorphisms (SNPs) in various genes $[8,9]$. Recently, much studies have been performed to investigate diverse mutations and SNPs in candidate genes involved in male infertility $[10,11]$. Miscellaneous variants in CATSPER1, SPATA16, and TEX11 genes are identified that play important roles in pathogenesis of sperm morphology (teratozoospermia), sperm motility parameters (asthenozoospermia), or sperm number (oligozoospermia or azoospermia) in human [12].

The cation channel of sperm associated (CATSPER1) gene is encodes an ion channel that involved in calcium $\left(\mathrm{Ca}^{2+}\right)$ transport and play an important role in sperm motility [13]. Recently, association of CATSPER1 gene variants with male infertility was reported [14]. The insertion mutations in this gene can cause to reduced fertility through sperm defects and asthenozoospermia [15]. In addition, other sperm defects such as low sperm count, reduced semen volume, non-motile sperm or reduced sperm motility, and increased structural abnormality in spermatozoa are reported in infertile males with CATSPER1 gene mutation [14].

The spermatogenesis associated (SPATA16) gene is encodes a protein located in Golgi apparatus and proacrosomic vesicles which is associated with globozoospermia [16]. This gene plays an important role in spermatogenesis and sperm production with a major role in development of testis. Expression of SPATA16 gene is extremely upregulated in human testes during puberty [17]. Several mutations and SNPs on this gene are reported in patients with non-syndromic monogenic male infertility [18].

The testis expressed (TEX11) gene is encodes a tetratricopeptide repeat motif that located in cytoplasm and spermatogonia nuclei type B and involved in proteinprotein interactions in human [19]. This gene is exclusively expressed in human testis with the highest level in the zygotene phase of spermatocytes, and a basal level in late pachytene phase of spermatocytes [20, 21]. High expression of TEX11 gene in early spermatocytes and spermatogonia type $\mathrm{B}$ indicate that TEX11 gene plays a critical role in early stage of germ cells development [21].

To date, association of CATSPER1 (rs2845570), SPATA16 (rs1515442), and TEX11 (rs143246552) genes polymorphism and male infertility was not investigated in Iranian Azeri population. Therefore, we investigated association of these polymorphisms and idiopathic male infertility in Iranian Azeri patients with idiopathic azoospermia and oligospermia.

\section{Methods \\ Study subjects}

In this case-control study, we recruited 200 Iranian Azeri men (25-50 years old) who were referred to Department of Infertility, Valiasr Hospital, Tabriz, Iran, during January 2018-December 2020. The case group consisted of 100 infertile males with confirmed idiopathic azoospermia and oligospermia using semen analysis. The control group consisted of 100 healthy fertile males without any abnormal sperm. The infertile males with ejaculatory duct obstruction, hypogonadotropic, orchitis, hypogonadism, cryptorchidism, as well as abnormal karyotype and/or microdeletions on $\mathrm{Y}$ chromosome were excluded from study. The characteristics and demographic variables of all subjects, (age, body mass index-BMI, alcohol drinking, tobacco smoking, family history of azoospermia and/or oligospermia, and semen parameters) were collected by questionnaires and interviews (Table 1). To prevent epidemiological bias, all studied subjects were recruited from the East Azerbaijan province, Iran. All participants were matched for age, races, and ethnic, as well as were genetically unrelated. This study was confirmed by ethical committee of Islamic Azad University, North Tehran Branch, Tehran, Iran (The ethical code: IR.IAU.TNB.REC.1399.030). The subjects were informed about the study, and signed a consent form according to the Declaration of Helsinki ethical standards.

\section{DNA extraction}

The peripheral blood sample $(3 \mathrm{ml})$ were received from all patients and healthy controls, and collected into vials containing Ethylene diamine tetraacetic acid (EDTA) as an anticoagulant. The proteinase $\mathrm{K}$ method was employed to extraction of genomic DNA from collected peripheral blood samples. The nanodrop instrument was used to confirm quantity of the extracted DNA samples according to OD 260/280 ratio (desirable ratio was 1.71.9). Also, agarose gel electrophoresis was used to confirm quality of the extracted DNA samples. The genomic DNA samples with acceptable quantity and quality were stored at $-20^{\circ} \mathrm{C}$ until genotyping.

\section{Primer design and synthesis}

The reference sequences of CATSPER1, SPATA16 and TEX11 genes was obtained from National Center for Biotechnology Information (NCBI) online database (https:// www.ncbi.nlm.nih.gov/gene). The primers design was conducted using Primer3 software for detection of CATSPER1 (rs2845570), SPATA16 (rs1515442) and TEX11 (rs143246552) genes polymorphism. The sequences of 
Table 1 The demographic variables and characteristics of the studied patients and healthy control

\begin{tabular}{|c|c|c|c|}
\hline Variables & Patients $(n=100)$ & Controls $(n=100)$ & $p$ Value \\
\hline Age (year $\pm S D$ ) & $29.33 \pm 2.78$ & $27.6 \pm 3.06$ & 0.298 \\
\hline $\mathrm{BMI}(\mathrm{kg} / \mathrm{m} \pm \mathrm{SD})$ & $26.25 \pm 2.18$ & $26.48 \pm 2.34$ & 0.699 \\
\hline \multicolumn{4}{|l|}{ Tobacco smoking } \\
\hline Never & $76(76 \%)$ & 89 (89\%) & - \\
\hline Ever & $34(34 \%)$ & $11(11 \%)$ & $0.004^{*}$ \\
\hline \multicolumn{4}{|l|}{ Alcohol drinking } \\
\hline Never & $39(39 \%)$ & $31(31 \%)$ & - \\
\hline Ever & $61(61 \%)$ & $69(69 \%)$ & 0.376 \\
\hline \multicolumn{4}{|l|}{ Family history } \\
\hline Negative & 79 (79\%) & $100(100 \%)$ & - \\
\hline Positive & $21(21 \%)$ & $0(0 \%)$ & $0.008^{*}$ \\
\hline \multicolumn{4}{|l|}{ Semen parameters } \\
\hline Concentration $(\times 106 / \mathrm{ml})$ & Median: 3.5 (0-6.37) & $125.5(94-156.3)$ & $<0.0001^{*}$ \\
\hline Mann Whitney test & Mean: $3.71 \pm 3.94$ & $126 \pm 40.3$ & \\
\hline Motility (\%) & Median: 48.5 (0-63) & $60(49-70)$ & $<0.0001^{*}$ \\
\hline Mann Whitney test & Mean: $33.95 \pm 30.48$ & $59.6 \pm 11.55$ & \\
\hline Volume (ml) & Median: 3.5 (2.35-4) & $4(3-5)$ & $<0.0001^{*}$ \\
\hline Mann Whitney test & Mean: $3.23 \pm 1$ & $4.18 \pm 3.19$ & \\
\hline
\end{tabular}

*Statistically Significant $p<0.05, B M I$ body mass index

the designed primers were sent to SinaClon Company, Iran for synthesis. The characteristics and sequences of the synthesized primers are presented in Table 2.

\section{DNA genotyping}

Genotyping analysis of the obtained DNA samples from patients and control group was performed using tetraprimer amplification refractory mutation system-polymerase chain reaction (Tetra-ARMS-PCR) method and specific primers (Table 2) for CATSPER1 (rs2845570), SPATA16 (rs1515442) and TEX11 (rs143246552) genes polymorphism. PCR amplification was conducted in a 25 $\mu \mathrm{L}$ total volume: template DNA (50 ng), forward primer (250 nM), reverse primer (250 nM), PCR Master Mix
$(1 \times)$. The condition of PCR reaction was as following: 1 cycle initial denaturation for $5 \mathrm{~min}$ in $94{ }^{\circ} \mathrm{C}, 30$ cycles denaturation for $5 \mathrm{~min}$ in $94^{\circ} \mathrm{C}, 30$ cycles annealing for $45 \mathrm{~s}, 30$ cycles extension for $45 \mathrm{~s}$ in $72{ }^{\circ} \mathrm{C}, 1$ cycle final extension for $5 \mathrm{~min}$ in $72{ }^{\circ} \mathrm{C}$. The obtained PCR products were electrophoresed on $2 \%$ agarose gel, and DNA bands size were estimated by a $50 \mathrm{bp}$ marker (ladder). Presence of each alleles was detected according to bands size as showed in Table 2.

\section{Statistical analysis}

The obtained data were analyzed using statistical SPSS software (version 21.0). Association of CATSPER1 (rs2845570), SPATA16 (rs1515442) and TEX11

Table 2 The characteristics and sequences of primers used for detection of genes polymorphisms

\begin{tabular}{|c|c|c|}
\hline Gene (polymorphism) & Primer sequence $\left(5^{\prime} \rightarrow 3^{\prime}\right)$ & Products size: allele type \\
\hline CATSPER1 (rs2845570) & $\begin{array}{l}\text { Forward outer: TCCAGCATGACGGTGTTGAGGCAGA } \\
\text { Reverse outer: ATATTCTTCTGCATCTACGTGGTGG } \\
\text { Forward inner:TTCTTGCGGGTCCGCTGGAGCCG } \\
\text { Reverse inner:TCTGGCCCTGTTCCTTTCAGCCGGCA }\end{array}$ & $\begin{array}{l}323 \text { bp: allele } G(A) \\
473 \text { bp: - } \\
198 \text { bp: allele T }(B)\end{array}$ \\
\hline SPATA16 (rs1515442) & $\begin{array}{l}\text { Forward outer: TAACATCCTGGAAATGTCACAAGAG } \\
\text { Reverse outer: TTCTTTAATCCCATACCTCAAGTGC } \\
\text { Forward inner: ATGAAGTTGGTCTACATTGATGAAA } \\
\text { Reverse inner: CTACAAACTCATAGCGAACACCCAC }\end{array}$ & $\begin{array}{l}256 \text { bp: allele T (A) } \\
515 \text { bp: - } \\
308 \text { bp: allele C (B) }\end{array}$ \\
\hline TEX11 (rs143246552) & $\begin{array}{l}\text { Forward outer: ATAGATTCCAATCAGCATTAGTAACATC } \\
\text { Reverse outer: AGGATTCAATATTTTCTCCAATATTCCC } \\
\text { Forward inner: TCACTCTCAACAGTAATCTTCTCCAT } \\
\text { Reverse inner: CCCTGAGGCTGACTTGACCG }\end{array}$ & $\begin{array}{l}348 \text { bp: allele T }(A) \\
563 \text { bp: - } \\
470 \text { bp: allele C (B) }\end{array}$ \\
\hline
\end{tabular}


(rs143246552) genes polymorphism with azoospermia and oligospermia were investigated using logistic regression. Fisher's exact test and chi-square $\left(x^{2}\right)$ test were used to analysis of Hardy-Weinberg equilibrium (HWE) in genotypes distribution of case and control groups. Differences in demographic variables and characteristics of the studied infertile patients and healthy controls were analyzed by independent sample t-test. The statistically significant was considered as $p<0.05$.

\section{Results}

\section{Demographic characteristics}

The demographic variables and characteristics of patients and healthy controls are presented in Table 1. The statistical analysis demonstrated that there were no significant differences between patients and healthy controls in terms of alcohol drinking, body mass index (BMI), and age $(p>0.05)$; whereas we find a significant difference between patients and healthy controls in term of positive family history of infertility and tobacco smoking $(p<0.05)$. These results indicated that the positive family history and tobacco smoking can cause to increase male azoospermia and oligospermia risk.

\section{Hardy-Weinberg equilibrium}

The statistical analysis indicated that the genotype distribution of CATSPER1 (rs2845570), SPATA16 (rs1515442) and TEX11 (rs143246552) genes polymorphism in patients and healthy controls were in agreement with HWE $(p>0.05)$.

\section{Genotype and allele distribution}

The genotype and allele distribution of patients and healthy controls are presented in Table 3. Our study indicated a significant correlation between CATSPER1 (rs2845570) and SPATA16 (rs1515442) genes polymorphisms and idiopathic azoospermia and oligospermia; whereas, no correlation was found between TEX11 (rs143246552) gene polymorphism and idiopathic azoospermia and oligospermia (Table 3 ).

In the CATSPER1 (rs2845570) gene polymorphism, frequency of wild homozygous (GG), heterozygous (GT), and mutant homozygous (TT) genotypes in case group are $81 \%, 14 \%$ and $5 \%$, respectively. Whereas, frequency of GG, GT, and TT genotypes in case group are $98 \%, 2 \%$ and $0 \%$, respectively. The obtained results demonstrated a significant increased risk of idiopathic azoospermia and oligospermia in patients with $\mathrm{AB}(p=0.001 ; \mathrm{OR}=8.47$; 95\% CI: $2.14-38.1)$ and BB ( $p=0.021$; OR = infinity; $95 \%$ CI: 1.7-infinity) genotypes. We suggested that presence of B mutant allele can cause to significantly increase in idiopathic azoospermia and oligospermia (Table 3).
In the SPATA16 (rs1515442) gene polymorphism, frequency of wild homozygous (TT), heterozygous (TC), and mutant homozygous (CC) genotypes in case group are $87 \%, 12 \%$ and $1 \%$, respectively. Whereas, frequency of TT, TC, and CC genotypes in control group are $96 \%, 4 \%$ and $0 \%$, respectively. We indicated that the heterozygote $\mathrm{AB}(p=0.039$; $\mathrm{OR}=3.31 ; 95 \%$ CI $1.01-9.61)$ genotype can cause to a significant increase in risk of idiopathic azoospermia and oligospermia (Table 3 ).

In the TEX11 (rs143246552) gene polymorphism, frequency of wild homozygous (TT), heterozygous (TC), and mutant homozygous (CC) genotypes case group are $95 \%, 2 \%$ and $3 \%$, respectively. Whereas, frequency of TT, $\mathrm{TC}$, and CC genotypes in control group are $98 \%, 2 \%$ and $0 \%$, respectively. We did not find any significant correlation between TEX11 (rs143246552) gene polymorphism and idiopathic azoospermia and oligospermia (Table 3).

\section{Discussion}

Infertility is defined as the inability to conceive after at least twelve months of regular and unprotected intercourse [22]. Idiopathic azoospermia and oligospermia are the common type of male infertility, which has recently become a research focus. The azoospermia and oligospermia etiology are includes abnormal immunity, infection, endocrine dysfunction, abnormal semen liquefaction, chromosomal abnormalities, varicocele, and abnormal sperm structure. Idiopathic azoospermia and oligospermia, with complex molecular mechanisms, can cause to abnormal sperm quantity that closely associated with abnormal fertilization [23, 24]. In the recent years, extensive studies have been performed to identify of molecular mechanisms of male infertility; however, a large proportion of male infertility cases are idiopathic. Evidence suggested that the common genetic causes of male azoospermia or oligospermia are related to mutations and SNPs on involved genes in spermatogenesis [7, 25].

In the present study, we recruited 100 patients with idiopathic male infertility (azoospermia and/or oligospermia) and 100 healthy controls from Iranian Azeri population in order to investigate correlation of CATSPER1 (rs2845570), SPATA16 (rs1515442), and TEX11 (rs143246552) genes polymorphism with idiopathic azoospermia and oligospermia risk. We demonstrated a correlation between CATSPER1 (rs2845570) and SPATA16 (rs1515442) genes polymorphisms with idiopathic azoospermia and oligospermia. However, no correlation was observed between TEX11 (rs143246552) gene polymorphism and idiopathic azoospermia and oligospermia.

Previous studies have demonstrated that CATSPER1 gene is strongly associated with sperm motility as well as acrosome reaction and sperm hyper-activation [26, 27]. 
Table 3 Genotype and allele frequencies of the studied polymorphisms in patients and healthy control

\begin{tabular}{|c|c|c|c|c|c|c|}
\hline Gene (polymorphism) & Inheritance models & Genotype and Allele & Case (\%) & Control (\%) & $p$ Value & OR $(95 \% \mathrm{Cl})$ \\
\hline \multirow[t]{11}{*}{ CATSPER1 (rs2845570) } & \multirow[t]{3}{*}{ Codominant } & GG & 81 (81\%) & $98(98 \%)$ & Ref & $\operatorname{Ref}=1$ \\
\hline & & GT & $14(14 \%)$ & $2(2 \%)$ & $0.001 *$ & $8.47(2.14-38.1)$ \\
\hline & & $\mathrm{TT}$ & $5(5 \%)$ & $0(0 \%)$ & $0.021^{*}$ & Infinity (1.7-infinity) \\
\hline & \multirow[t]{2}{*}{ Dominant } & GG & 81 (81\%) & 98 (98\%) & Ref & $\operatorname{Ref}=1$ \\
\hline & & $\mathrm{GT}+\mathrm{GG}$ & $19(19 \%)$ & $2(2 \%)$ & $0.0001 *$ & $11.49(2.8-50.7)$ \\
\hline & \multirow[t]{2}{*}{ Recessive } & $\mathrm{TT}$ & $5(5 \%)$ & $0(0 \%)$ & Ref & $\operatorname{Ref}=1$ \\
\hline & & $\mathrm{GT}+\mathrm{GG}$ & 95 (95\%) & $100(100 \%)$ & 0.059 & Infinity (1.5-infinity) \\
\hline & \multirow[t]{2}{*}{ Overdominant } & GT & $14(14 \%)$ & $2(2 \%)$ & Ref & $\operatorname{Ref}=1$ \\
\hline & & $\mathrm{GG}+\mathrm{TT}$ & $86(86 \%)$ & $98(98 \%)$ & $0.0029 *$ & $7.97(2.02-35.8)$ \\
\hline & \multirow[t]{2}{*}{ Alleles } & G wild & $176(88 \%)$ & 198 (99\%) & Ref & $\operatorname{Ref}=1$ \\
\hline & & T mutant & $24(12 \%)$ & $2(1 \%)$ & $0.0001 *$ & $13.5(3.6-58.4)$ \\
\hline \multirow[t]{11}{*}{ SPATA16 (rs1515442) } & \multirow[t]{3}{*}{ Codominant } & $\mathrm{TT}$ & $87(87 \%)$ & $96(96 \%)$ & Ref & $\operatorname{Ref}=1$ \\
\hline & & $\mathrm{TC}$ & $12(12 \%)$ & $4(4 \%)$ & $0.039 *$ & $3.31(1.01-9.61)$ \\
\hline & & $\mathrm{CC}$ & $1(1 \%)$ & $0(0 \%)$ & 0.478 & Infinity (0.12-infinity) \\
\hline & \multirow[t]{2}{*}{ Dominant } & $\mathrm{TT}$ & $87(87 \%)$ & $96(96 \%)$ & Ref & $\operatorname{Ref}=1$ \\
\hline & & $\mathrm{TC}+\mathrm{CC}$ & $13(13 \%)$ & $4(4 \%)$ & $0.039 *$ & $3.58(1.14-10.3)$ \\
\hline & \multirow[t]{2}{*}{ Recessive } & CC & $1(1 \%)$ & $0(1 \%)$ & Ref & $\operatorname{Ref}=1$ \\
\hline & & $\mathrm{TC}+\mathrm{TT}$ & 99 (99\%) & $100(100 \%)$ & $>0.999$ & Infinity (0.11-infinity) \\
\hline & \multirow[t]{2}{*}{ Overdominant } & TC & $12(12 \%)$ & $4(4 \%)$ & Ref & $\operatorname{Ref}=1$ \\
\hline & & $\mathrm{CC}+\mathrm{TT}$ & $88(88 \%)$ & $96(96 \%)$ & 0.065 & $3.27(1.0-9.5)$ \\
\hline & \multirow[t]{2}{*}{ Alleles } & T wild & $186(93 \%)$ & $196(98 \%)$ & Ref & $\operatorname{Ref}=1$ \\
\hline & & C mutant & $14(7 \%)$ & $4(2 \%)$ & $0.016^{*}$ & $3.69(1.2-10.4)$ \\
\hline \multirow[t]{11}{*}{ TEX11 (rs143246552) } & \multirow[t]{3}{*}{ Codominant } & $\mathrm{TT}$ & $95(95 \%)$ & $98(98 \%)$ & Ref & $\operatorname{Ref}=1$ \\
\hline & & $\mathrm{TC}$ & $2(2 \%)$ & $2(2 \%)$ & 0.999 & $1.03(0.815-6.7)$ \\
\hline & & $\mathrm{CC}$ & $3(3 \%)$ & $0(0 \%)$ & 0.246 & Infinity (0.87-infinity) \\
\hline & \multirow[t]{2}{*}{ Dominant } & $\mathrm{TT}$ & $95(95 \%)$ & $98(98 \%)$ & Ref & $\operatorname{Ref}=1$ \\
\hline & & $\mathrm{TC}+\mathrm{CC}$ & $5(5 \%)$ & $2(2 \%)$ & 0.444 & $2.58(0.53-13.1)$ \\
\hline & \multirow[t]{2}{*}{ Recessive } & CC & $3(3 \%)$ & $0(0 \%)$ & Ref & $\operatorname{Ref}=1$ \\
\hline & & $\mathrm{TC}+\mathrm{TT}$ & $97(97 \%)$ & $100(100 \%)$ & 0.246 & Infinity (0.87-infinity) \\
\hline & \multirow[t]{2}{*}{ Overdominant } & TC & $2(2 \%)$ & $2(2 \%)$ & Ref & $\operatorname{Ref}=1$ \\
\hline & & $\mathrm{CC}+\mathrm{TT}$ & $98(98 \%)$ & 98 (98\%) & 1 & $1(0.15-6.48)$ \\
\hline & \multirow[t]{2}{*}{ Alleles } & Twild & $192(96 \%)$ & 198 (99\%) & Ref & $\operatorname{Ref}=1$ \\
\hline & & C mutant & $8(4 \%)$ & $2(1 \%)$ & 0.055 & $4.12(1.0-19.4)$ \\
\hline
\end{tabular}

*Statistically Significant $p<0.05$

$O R$ odds ratio, $\mathrm{Cl}$ confidence interval

Moreover, clinical studies have reported that abnormal expression of CATSPER1 gene are associated with idiopathic infertility patients with decreased sperm motility $[28,29]$. So far, only two studies have been investigated association of CATSPER1 gene polymorphisms with idiopathic male infertility. In a study by Rahimpour Goushchi et al. [30] reported that the frequency of the CC allele in CATSPER1 rs1893316 polymorphism significantly increased in patients with male infertility in Iranian Azeri population. In another study by Shu et al. [31] reported that there is no significant association between CATSPER1 rs 2845570 polymorphism and male infertility in Chinese population. To our knowledge, the present study is the first report on significant association of CATSPER1 rs2845570 polymorphism and male infertility in the world.

Recently, studies have suggested that SPATA16 gene is involved in sperm production and can cause to globozoospermia, testicular diseases, spermatogenesis arrest, and sperm aneuploidy in human [32, 33]. So far, very limited studies have been reported on SPATA16 gene polymorphisms and male infertility. Therefore, the exact role of SPATA16 gene polymorphisms are unknown in molecular pathogenesis of male infertility. In a study by Roozbahani et al. (2017) reported that there is no significant association between SPATA16 rs137853118 exon 4 
polymorphism and male infertility in Iranian population [32]. In another study by Dom et al. [18] suggested that the homozygous c.848G > A mutation in SPATA16 gene can cause to male infertility with an autosomal recessive mode of transmission in three patients from a Jewish family. To our knowledge, this study is the first description in association of SPATA16 (rs1515442) genes polymorphism and male infertility in the world.

Evidence indicated that TEX11 gene is involved in chromosomal synapsis and meiotic recombination and can cause to oligozoospermia, azoospermia, meiotic arrest, and male infertility [34,35]. In recent years, two studies extensively investigated TEX11 gene polymorphisms correlation with male infertility [36, 37]. In a study by Sezavar et al. [36] reported that rs6525433 polymorphism in TEX11 gene were not associated with risk of azoospermia in Iranian patients with infertility. In another study by Zhang et al. [37] indicated that there is a significant association between TEX11 rs6525433 polymorphism and male infertility in Chinese population; whereas they found no significant association between TEX11 rs4844247 polymorphism and male infertility in this population. However, no study has been reported on effect of TEX11 rs143246552 polymorphism on male infertility. To our knowledge, our study is the first report on association lack of TEX11 rs143246552 polymorphism and male infertility in the world.

Results contradiction reported by different studies might be due to other involved genes SNPs that cause male infertility, differences in geographic area, sample size and sample selection bias, genetic background of population and heterogeneity in ethnicity and race, and environmental factors [38, 39].

\section{Conclusions}

In general, our study provided a more understanding of male infertility as a heterogeneous disorder, and suggested that CATSPER1 (rs2845570) and SPATA16 (rs1515442) genes polymorphism are significantly associated with the risk of idiopathic azoospermia and oligospermia in Iranian Azeri population. In addition, we found no significant association between SPATA16 (rs1515442) gene polymorphism and idiopathic azoospermia and oligospermia in Iranian Azeri population. Therefore, to access more accurate results in association of these polymorphisms with idiopathic azoospermia and oligospermia, more extensive studies are recommended with larger sample size on other populations, ethnic origins, and races.

\section{Abbreviations}

SNP: Single nucleotide polymorphism; Tetra-ARMS-PCR: Tetra-primer amplifcation refractory mutation system-polymerase Chain reaction; EDTA: Ethylene diamine tetraacetic acid; SPSS: Statistical package for the social sciences; HWE: Hardy-Weinberg equilibrium; OR: Odds ratios; Cl: Confidence interval; BMl: Body mass index; IVF: In vitro fertilization; NCBI: National center for biotechnology information.

\section{Acknowledgements}

This article was extracted from the Ph.D. project of Mohammadreza Behvarz where Dr. Seyed Ali Rahmani and Dr. Elham Siasi Torbati supervised, and Dr. Shahla Danaii and Dr. Maryam Bikhof Torbati advised this project. We thank the whole staff of Dr. Rahmani Medical Genetics Laboratory for assistance in the successful strategy of this study.

\section{Authors' contributions}

MB, SAR, EST: Execution, analysis, and interpretation of data; $M B, S D$ : Manuscript writing and analysis; MB, MBT: Clinical Consultant; SD: Clinical Consultant; SAR: participation in study design, manuscript drafting and critical discussion. All authors read and approved the final manuscript.

\section{Funding}

None.

\section{Availability of data and materials}

The datasets generated during the current study are available in the [zenodo] repository, Accession No.: 5885267 (https://zenodo.org/record/5885267).

\section{Declarations}

\section{Ethics approval and consent to participate}

The protocol for this study was approved by the Ethics Committee of the Islamic Azad University, North Tehran Branch, Tehran, Iran (The ethical code: IR.IAU.TNB.REC.1399.030) and was in line with the Helsinki declaration. The all participants provided informed consent documents.

\section{Consent for publication}

Not applicable.

\section{Competing interests}

The authors declare no competing interests.

\section{Author details}

${ }^{1}$ Department of Genetics, Faculty of Biological Science, North Tehran Branch, Islamic Azad University, Tehran, Iran. ${ }^{2}$ Department of Medical Genetics, School of Medicine, Tabriz University of Medical Sciences, Tabriz, Iran. ${ }^{3}$ Department of Gynecology, Eastern Azerbaijan ACECR ART Center, Eastern Azerbaijan Branch of ACECR, Tabriz, Iran. ${ }^{4}$ Department of Biology, Yadegar-e-Imam Khomeini (RAH) Shahr-e-Rey Branch, Islamic Azad University, Tehran, Iran.

Received: 29 October 2021 Accepted: 25 February 2022

Published online: 05 March 2022

\section{References}

1. Coutton C, Satre V, Arnoult C, Ray P. Genetics of male infertility: the new players. Med Sci. 2012;28(5):497-502.

2. Soheilyfar S, Nikyar T, Fathi Maroufi N, Mohebi Chamkhorami F, Amini Z, Ahmadi M, Haj Azimian S, Isazadeh A, Taefehshokr S, Taefehshokr N. Association of IL-10, IL-18, and IL-33 genetic polymorphisms with recurrent pregnancy loss risk in Iranian women. Gynecol Endocrinol. 2019;35(4):342-5.

3. Nasirpour H, Azari Key Y, Kazemipur N, Majidpour M, Mahdavi S, Hajazimian S, Issazadeh A, Taefehshokr S. Association of rubella, cytomegalovirus, and toxoplasma infections with recurrent miscarriages in Bonab-Iran: a case-control study. Gene Cell Tissue. 2017;4(3):e60891.

4. Hajizadeh YS, Emami E, Nottagh M, Amini Z, Maroufi NF, Azimian SH, Isazadeh A. Effects of interleukin-1 receptor antagonist (IL-1Ra) gene 86 bp VNTR polymorphism on recurrent pregnancy loss: a case-control study. Horm Mol Biol Clin Investig. 2017;30(3):20170010. 
5. Curi SM, Ariagno Jl, Chenlo PH, Mendeluk GR, Pugliese MN, Sardi Segovia LM, Repetto HE, Blanco AM. Asthenozoospermia: analysis of a large population. Arch Androl. 2003;49(5):343-9.

6. Isazadeh A, Hajazimian S, Rahmani SA, Mohammadoo-Khorasani M, Samanmanesh S, Karimkhanilouei S. The effects of Factor II (rs1799963) polymorphism on recurrent pregnancy loss in Iranian Azeri women. Riv Ital Med Lab. 2017;13(1):37-40.

7. Isazadeh A, Hajazimian S, Rahmani SA, Mohammadoo-Khorasani M, Moghtaran N, Maroufi NF. The effect of factor-xi (rs3756008) polymorphism on recurrent pregnancy loss in Iranian Azeri women. Gene Cell Tissue. 2017:4(1):e43717.

8. Shiralizadeh J, Barmaki H, Haiaty S, Faridvand Y, Mostafazadeh M, Mokarizadeh N, Kamrani A, Isazadeh A, Maroufi NF. The effects of high and lowdoses of folic acid on oxidation of protein levels during pregnancy: a randomized double-blind clinical trial. Horm Mol Biol Clin Investig. 2017;33(3):20170039

9. Isazadeh A, Azimian SH, Tariverdi N, Rahmani SA, Esmaeili M, Karimkhanilouei S, Mohammadoo-Khorasani M. Effects of coagulation factor XIII (Val34Leu) polymorphism on recurrent pregnancy loss in Iranian Azeri women. LaboratoriumsMedizin. 2017;41(2):89-92.

10. Jedidi I, Ouchari M, Yin Q. Autosomal single-gene disorders involved in human infertility. Saudi J Biol Sci. 2018;25(5):881-7.

11. Zorrilla M, Yatsenko AN. The genetics of infertility: current status of the field. Curr Genet Med Rep. 2013;1 (4):247-60.

12. Cannarella R, Condorelli RA, Duca Y, La Vignera S, Calogero AE. New insights into the genetics of spermatogenic failure: a review of the literature. Hum Genet. 2019:138(2):125-40.

13. Kirichok Y, Navarro B, Clapham DE. Whole-cell patch-clamp measurements of spermatozoa reveal an alkaline-activated Ca 2+ channel. Nature. 2006:439(7077):737-40.

14. Avenarius MR, Hildebrand MS, Zhang Y, Meyer NC, Smith LL, Kahrizi K, Najmabadi H, Smith RJ. Human male infertility caused by mutations in the CATSPER1 channel protein. Am J Hum Genet. 2009;84(4):505-10.

15. Hildebrand MS, Avenarius MR, Fellous M, Zhang Y, Meyer NC, Auer J, Serres C, Kahrizi K, Najmabadi H, Beckmann JS, Smith RJ. Genetic male infertility and mutation of CATSPER ion channels. Eur J Hum Genet. 2010;18(11):1178-84.

16. Perrin A, Coat C, Nguyen MH, Talagas M, Morel F, Amice J, De Braekeleer M. Molecular cytogenetic and genetic aspects of globozoospermia: a review. Andrologia. 2013:45(1):1-9.

17. Zhang Q, Zhang F, Chen XH, Wang YQ, Wang WQ, Lin AA, Cavalli-Sforza $L L$, Jin L, Huo R, Sha JH, Li Z. Rapid evolution, genetic variations, and functional association of the human spermatogenesis-related gene NYDSP12. J Mol Evol. 2007;65(2):154-61.

18. Dam AH, Koscinski I, Kremer JA, Moutou C, Jaeger AS, Oudakker AR, Tournaye H, Charlet N, Lagier-Tourenne C, van Bokhoven H, Viville S. Homozygous mutation in SPATA16 is associated with male infertility in human globozoospermia. Am J Hum Genet. 2007;81 (4):813-20.

19. Chelysheva L, Gendrot G, Vezon D, Doutriaux MP, Mercier R, Grelon M. Zip4/Spo22 is required for class I CO formation but not for synapsis completion in Arabidopsis thaliana. PLoS Genet. 2007;3(5):e83.

20. Adelman CA, Petrini JH. ZIP4H (TEX11) deficiency in the mouse impairs meiotic double strand break repair and the regulation of crossing over. PLoS Genet. 2008;4(3):e1000042.

21. Yang F, Gell K, Van Der Heijden GW, Eckardt S, Leu NA, Page DC, Benavente R, Her C, Höög C, McLaughlin KJ, Wang PJ. Meiotic failure in male mice lacking an X-linked factor. Genes Dev. 2008;22(5):682-91.

22. Massart A, Lissens W, Tournaye H, Stouffs K. Genetic causes of spermatogenic failure. Asian J Androl. 2012;14(1):40-8.

23. Tamburrino L, Marchiani S, Minetti F, Forti G, Muratori M, Baldi E. The CatSper calcium channel in human sperm: relation with motility and involvement in progesterone-induced acrosome reaction. Hum Reprod. 2014;29(3):418-28.

24. Guerri G, Maniscalchi T, Barati S, Gerli S, Di Renzo GC, Della Morte C, Marceddu G, Casadei A, Laganà AS, Sturla D, Ghezzi F. Non-syndromic monogenic female infertility. Acta Biomed. 2019:90(Suppl 10):68-74.

25. Reijo R, Lee TY, Salo P, Alagappan R, Brown LG, Rosenberg M, Rozen S, Jaffe T, Straus D, Hovatta O, de la Chapelle A. Diverse spermatogenic defects in humans caused by $Y$ chromosome deletions encompassing a novel RNA-binding protein gene. Nat Genet. 1995;10(4):383-93.
26. Qi H, Moran MM, Navarro B, Chong JA, Krapivinsky G, Krapivinsky L, Kirichok Y, Ramsey IS, Quill TA, Clapham DE. All four CatSper ion channel proteins are required for male fertility and sperm cell hyperactivated motility. Proc Natl Acad Sci. 2007;104(4):1219-23.

27. Xia J, Ren D. Egg coat proteins activate calcium entry into mouse sperm via CATSPER channels. Biol Reprod. 2009;80(6):1092-8.

28. Nikpoor P, Mowla SJ, Movahedin M, Ziaee SA, Tiraihi T. CatSper gene expression in postnatal development of mouse testis and in subfertile men with deficient sperm motility. Hum Reprod. 2004;19(1):124-8.

29. Li HG, Liao AH, Ding XF, Zhou H, Xiong CL. The expression and significance of CATSPER1 in human testis and ejaculated spermatozoa. Asian J Androl. 2006:8(3):301-6.

30. Rahimpour Goushchi S, Rahmani SA, Maleki M. Investigating the correlation of polymorphism (rs1893316) Catsper1 gene with asthenozoospermia in men that referred into infertility treatment clinics of east azarbaijan of ACECR. New Cell Mol Biotechnol J. 2017;7(27):99-107.

31. Shu F, Zhou X, Li F, Lu D, Lei B, Li Q, Yang Y, Yang X, Shi R, Mao X. Analysis of the correlation of CATSPER single nucleotide polymorphisms (SNPS) with idiopathic asthenospermia. J Assist Reprod Genet. 2015;32(11):1643-9.

32. Roozbahani GA, Sheidai M, Noormohammadi Z, Gourabi H. Association study of SPATA-16 polymorphism with male infertility in Iranian population. Meta Gene. 2017;13:154-8.

33. Faja F, Pallotti F, Cargnelutti F, Senofonte G, Carlini T, Lenzi A, Lombardo F, Paoli D. Molecular analysis of DPY19L2, PICK1 and SPATA16 in Italian unrelated globozoospermic men. Life. 2021;11(7):641.

34. Yatsenko AN, Georgiadis AP, Röpke A, Berman AJ, Jaffe T, Olszewska M, Westernströer B, Sanfilippo J, Kurpisz M, Rajkovic A, Yatsenko SA. X-linked TEX11 mutations, meiotic arrest, and azoospermia in infertile men. N Engl J Med. 2015;372(22):2097-107.

35. Yang F, Silber S, Leu NA, Oates RD, Marszalek JD, Skaletsky H, Brown LG, Rozen S, Page DC, Wang PJ. TEX11 is mutated in infertile men with azoospermia and regulates genome-wide recombination rates in mouse. EMBO Mol Med. 2015;7(9):1198-210.

36. Sezavar H, Noormohammadi Z, Sheidai M. The study of the association of two variants of MLH3 (rs175080) andTEX11 (rs6525433) in Iranian infertile men. Iran J Biol Sci. 2020;14(4):31-41.

37. Zhang $X$, Ding M, Ding $X, L i T$, Chen $H$. Six polymorphisms in genes involved in DNA double-strand break repair and chromosome synapsis: association with male infertility. Syst Biol Reprod Med. 2015;61(4):187-93.

38. Fathi Maroufi N, Gholampour Matin M, Ghanbari N, Khorrami A, Amini Z, Haj Azimian S, Isazadeh A, Taefehshokr S, Taefehshokr N, Baradaran B. Influence of single nucleotide polymorphism in IL-27 and IL-33 genes on breast cancer. Br J Biomed Sci. 2019;76(2):89-91.

39. Maroufi NF, Aghayi E, Garshasbi H, Matin MG, Bedoustani AB, Amoudizaj FF, Hajazimian S, Isazadeh A, Taefehshokr S, Taefehshokr N, Baradaran B. Association of rs $1946518 \mathrm{C} / \mathrm{A}$ polymorphism in promoter region of interleukin 18 gene and breast cancer risk in Iranian women: a case-control study. Iran J Allergy Asthma Immunol. 2019;18(6):671-8.

\section{Publisher's Note}

Springer Nature remains neutral with regard to jurisdictional claims in published maps and institutional affiliations.

Ready to submit your research? Choose BMC and benefit from:

- fast, convenient online submission

- thorough peer review by experienced researchers in your field

- rapid publication on acceptance

- support for research data, including large and complex data types

- gold Open Access which fosters wider collaboration and increased citations

- maximum visibility for your research: over $100 \mathrm{M}$ website views per year

At BMC, research is always in progress.

Learn more biomedcentral.com/submissions 